\title{
The relevance of human capital to firm performance: A focus on the retail industry in Kinshasa, Democratic Republic of Congo
}

\author{
Authors: \\ Boris Urban \\ Michael Kongo ${ }^{1}$ \\ Affiliations: \\ ${ }^{1}$ Wits Business School, \\ Witwatersrand, South Africa \\ Correspondence to: \\ Boris Urban \\ Email: \\ boris.urban@wits.ac.za \\ Postal address: \\ PO Box 98, Witwatersrand \\ 2050, South Africa \\ Dates: \\ Received: 25 Mar. 2014 \\ Accepted: 30 Sept. 2014 \\ Published: 20 Mar. 2015 \\ How to cite this article: \\ Urban, U. \& Kongo, M., 2015, \\ 'The relevance of human \\ capital to firm performance: \\ A focus on the retail industry \\ in Kinshasa, Democratic \\ Republic of Congo', Acta \\ Commercii 15(1), Art. \#261, \\ 9 pages. http://dx.doi. \\ org/10.4102/ac.v15i1.261

\section{Copyright:} \\ C 2015. The Authors. \\ Licensee: AOSIS \\ OpenJournals. This work is \\ licensed under the Creative \\ Commons Attribution \\ License.
}

Purpose and problem: Human capital represents an investment in education and skills. However, in the Democratic Republic of Congo (DRC) the ability of small-scale retailers to grow and increase firm performance is restricted by the scarcity of education and prior work experience.

Methodology: Survey data were collected from 126 owner-managers in the retail industry in Kinshasa, DRC, in order to investigate the proposed relationship between the human capital components of education, work experience and venture performance.

Findings: Several variables pertaining to education and prior work experience were related to different aspects of venture performance, allowing for support of the hypotheses. Nonetheless, when clustering was conducted some surprising results were observed in that owner-managers tended to have little work experience even where their venture was performing well.

Implications: Research into human capital and links to performance in Africa and emerging markets is valuable as recent research has found that the matching of entrepreneurial human capital with opportunities for growth is the essence of economic development.

\section{Introduction}

The Democratic Republic of Congo (DRC), located in central Africa, has over the past decades experienced rapid urbanisation and overpopulation in its capital Kinshasa, resulting in chaos, inequalities, poverty, environmental degradation, socio-economic tension and spontaneous settlements and sprawl. Such rapid urban growth typically occurs without planning or productive employment, which is compounded by weak government involvement (Nsokimieno, Shouyu \& Qin 2010). This chaotic situation has encouraged the average citizen to become self-employed, which most often manifests as a survivalist street-vendor type of business venture (Coyne \& Pellillo 2011; Iyenda 2005).

This scenario exists not only in the DRC: a small large-scale and a large small-scale sector characterise most African economies. In between is the medium-scale sector, which has been called the 'missing middle' in African economies. Only 2\% of all African ventures have 10 or more employees. The majority are microenterprises and small-scale enterprises that consist of one to three employees, mostly in the informal sector (McDade \& Spring 2005:19). Informal microenterprises provide, on average, half of all economic activity in developing countries; however, when compared to formal enterprises these enterprises are unproductive, serving mainly as a social security net keeping millions of people alive, but disappearing over time (La Porta \& Schleifer 2008).

Understanding the informal sector as an entrepreneurial space is subject to some debate. Conventionally, the 'marginalists' understand people entering the informal sector as having little other option. This perspective is prevalent in the Global Entrepreneurship Monitor (GEM) series of reports, which find that entrepreneurial activity in Africa, in comparison to other regions, is heavily skewed toward low-expectation entrepreneurial activity (Von Broembsen, Wood \& Herrington 2005). On the other hand, the 'structuralists' contend that people participating in the informal sector exhibit strong entrepreneurial tendencies and, more importantly, do so by choice (Williams 2007; Yaw 2007). Whilst this perspective is arguably more contentious, it does underscore the notion that informal traders might be seen as innovative, opportunity-driven individuals and, indeed, that the informal sector gives rise to a 'hidden' enterprise culture, which ultimately needs to be harnessed and drawn into the formal economy (Williams 2007).

The problem of the present study is drawn from the situation wherein even though many policymakers view the informal sector and small, medium and microenterprises (SMMEs) as 
one of the solutions to boosting Africa's deprived economies (Awogbenle \& Iwuamadi 2010; Chisala 2008), the ability of these SMMEs to grow and create employment is restricted by the scarcity of education, skills, venture knowledge and access to resources (Von Broembsen et al. 2005). Several authors have argued that resources and assets (both tangible and intangible) are accumulated throughout entrepreneurial careers and are important in building a human capital base (Borchert \& Zellmer-Bruhn 2010; Matshekga \& Urban 2013; Unger et al. 2011). Human capital represents an investment in education and skills and entrepreneurs provide tangible and intangible resources to a venture. These intangible resources are the properties individuals have accumulated through education and experience (Shree \& Urban 2012).

However, human capital does not always have a positive effect on venture performance (Chawla, Khanna \& Chen 2010). For instance, research has shown that over-investment in education leading to high levels of certification may discourage risk-taking, whilst under-investment may encourage it. For this reason, migrants are frequently engaged in entrepreneurial activities: they reside in a new social structure that may not reward their formal human capital investments (Davidsson \& Honig 2003:301-331). Human capital has also been shown to have a negative or non-linear effect on entrepreneurship when individuals with higher levels of education, particularly in developing economies, often seek employment in the formal economy, for jobs that pay well (Amaral, Baptista \& Lima 2011). On the other hand, external conditions in a particular country, region or city may lead to even well-educated individuals who are presented with limited opportunities for satisfying and sufficiently rewarding employment to engage in entrepreneurship. As a result, many entrepreneurs in developing environments are well equipped to identify and exploit opportunities even if the initial reasons for becoming an entrepreneur may reasonably be described as 'necessity entrepreneurship' (Xavier et al. 2013:14).

\section{Purpose and objectives}

Recognising the mixed findings of the relationship between human capital and entrepreneurship (Unger et al. 2011), and by building on existing theory and empirical studies, the research question of the present study becomes: to what extent are the human capital variables of education and experience pertinent for entrepreneurial success in the retail industry in Kinshasa? To address the research question a diverse sample of entrepreneurs in the greater Kinshasa area were assembled to empirically determine which human capital variables are important when measuring venture performance. The study employed a survey to collect data and statistical tests were used to determine the relative importance attributed to each of the human capital variables in terms of clusters analysis.

This study is important when considering that in many African countries, such as South Africa, Nigeria and Ghana, governments have introduced policies not only to encourage entrepreneurship but also to increase or create more human capital so that entrepreneurship can flourish (Mitra, Abubakar \& Sagagi 2011; Saffu et al. 2008). Indeed, Oluwatobi and Ogunrinola (2011) argue that human capital is one of the most important factors that is accountable for the wealth of nations and that human capital needs to be strategically cultivated and positioned for the preservation of both the present and the future economic growth and development of a country. Human capital development has the capacity to enlarge people's choices and opportunities through acquired skills and knowledge and eventually to enhance growth in the nation's gross domestic product (GDP) through increased productivity (Gimmon \& Levie 2009).

\section{Human capital and entrepreneurship}

The theory of human capital is rooted in the field of macroeconomic development theory, where Becker (1964) emphasised the social and economic importance of human capital theory and noted that the most valuable of all capitals is the investment in human beings. Theodore Schultz (1970) developed a theory of entrepreneurship based on this concept of human capital. He conceptualised entrepreneurs as being able to deal with disequilibrium: individuals engage in optimising behaviour which entails reallocating resources to regain equilibrium. Human capital theory maintains that knowledge increases individuals' cognitive abilities, leading to more productive and efficient potential activity. Once engaged in the entrepreneurial process, such individuals should also have superior ability in successfully exploiting opportunities. Further, the level of previous investment in human capital, such as education, may influence life career choices, including attitudes towards entrepreneurial activity, in various ways (Schultz 1970).

Unger et al. (2011) conceptualise human capital as skills and knowledge that individuals acquire through investments in schooling, on-the-job training and other types of experience; the ability to act entrepreneurially is related to human capital variables such as education, work experience, entrepreneurial experience, prior knowledge and experiential knowledge.

Human capital, in the entrepreneurship literature is often operationalised by the level and type of education of the founding entrepreneurs. Characteristics such as education type and education level are widely accepted as having a positive relationship to venture growth (Autio 2007). Formal education is one component of human capital that may assist in the accumulation of explicit knowledge that may provide skills useful to entrepreneurs. Human capital theorists surmise that education is an investment that yields higher wage compensation in return for an individual's variations of skills, training and experience (Davidsson \& Honig 2003). Despite early notions that entrepreneurs are less well-educated than the general population, empirical evidence suggests that entrepreneurs have a higher level of education than non-entrepreneurs (Mansor \& Othman 2011). Investigating the relationship between entrepreneurship and education, it has been reported that secondary education (high school) and post-secondary education (tertiary) effect 
entrepreneurial activity levels (Autio 2007). Nonetheless, the relationship between education and entrepreneurial activity is complex. Levels of education are commonly considered to have implications for different types of entrepreneurial behaviour. Research on the relationship between education and entrepreneurship shows that: (1) better-educated entrepreneurs pursue more opportunity-based ventures, (2) less well-educated entrepreneurs are involved out of necessity and (3) people who have a secondary-level education (high school) tend to work for salaries or wages (Xavier et al. 2013).

Research also demonstrates that entrepreneurship education increases an individual's self-confidence, general knowledge and self-efficacy and ultimately their human capital, which in turn increases their perceptions of feasibility and desirability of pursuing entrepreneurship (Krueger \& Brazeal 1994; Urban 2012). Past research has demonstrated a positive relationship between higher educational qualifications and venture growth. Additionally, education helps to enhance the entrepreneur's exploratory skills and improves communication abilities and foresight (Dobbs \& Hamilton 2007; Mansor \& Othman 2011). Such findings and similar research suggest that entrepreneurs with undergraduate degrees are more likely to be less financially constrained than those only a high school educational background (Unger et al. 2011:349).

The importance of education as a form of general human capital has been established in several studies: individuals with higher educational levels are more likely to participate in venture start-ups and the performance of their ventures will likely be significantly higher (Gimmon \& Levie 2009). This notion of venture performance is important when considering that past research has found a positive relationship between management experience and venture growth (Urban, Van Vuuren \& Barreira 2008). Moreover, the terms 'growth', 'success' and 'performance' are often used interchangeably in entrepreneurship research and are typically measured using indicators such as: (1) earnings, (2) net worth, (3) cash flow, (4) market share and (5) sales volume (Reijonen \& Kompula 2007:689).

Financial indicators are probably the most common form of performance measures across all venture types, even though they are primarily one-dimensional measures, which are biased towards short-term profitability at the expense of longterm growth (Hitt, Shimizu \& Kochhar 2001). Consequently, the use of non-financial measures is increasingly being adopted by ventures with a focus on issues such as customer satisfaction, customer referral rates, delivery time, waiting time and employee turnover (St-Pierre, Julien \& Morin 2010).

Following the literature on the evolving nature and different methods used for assessing human capital and venture performance, venture performance is hypothesised to be associated with the human capital dimension of education:

Hypothesis 1: The human capital dimension of education is positively related to venture performance.
Additionally, entrepreneurial human capital provides the following advantages: (1) capabilities to discover new venture opportunities, (2) capabilities to exploit opportunities and (3) capabilities to consolidate and grow the current venture (Unger et al. 2011). Rauch, Frese and Utsch (2005) argue that there are two ways in which a founder's previous experience impacts venture performance: firstly, it leads to the development of experientially acquired skills or expertise, which will lead in turn to more knowledgeable actions and decisions. Secondly, as founders are inclined to start ventures that are similar (e.g. in terms of ind ustry or geographic area) to ventures with which they are familiar, experience influences start-up characteristics. Dobbs and Hamilton (2007) emphasise the positive effect of past experience on small venture growth by proposing that owner-managers with previous experience are more likely to avoid costly mistakes than those with no prior experience. Moreover, entrepreneurs with previous work experience in accountancy or finance are more likely to have a broader and deeper knowledge of finance alternatives compared to entrepreneurs without experience in these areas (Seghers, Manigart \& Vanacker 2009). Additionally, prior venture ownership and work experience has been associated with assets like extended networks, increased expertise and a solid reputation with financiers, customers and suppliers (Urban et al. 2008).

Furthermore, studies show a positive link between the levels of human capital present in the venture and that of the venture's employees and performance. This suggests human capital is the outcome of a venture's calculated investment through the hiring of employees with high general skills (formal education) added to a venture investment in training of more specific skills through training activities (Roca-Puig, Beltra'n-Martın \& Cipres 2012). Work experience in the entrepreneurship domain includes having dealt with start-up problems such as generating sales, developing marketing avenues and tactics, obtaining external financing and dealing with internal financial and general management issues (Seghers et al. 2009).

Acknowledging the past research highlighting the importance of work experience towards increased venture performance, it is proposed that:

Hypothesis 2: The human capital dimension of work experience is positively related to venture performance.

\section{Research design}

The research design was cross-sectional and relied on a quantitative survey to collect data in order to investigate the proposed relationship between the human capital components of education, work experience and venture performance. The context of the study was the retail industry in Kinshasa, DRC. By focusing on a single industry sector, a greater homogeneity of context is achieved, which addresses the concerns of broad applicability versus perfect suitability for narrower groups. Studies across industries often produce results that apply to all whilst they at the same time apply to none (Davidsson 2004). Subsequently, the focus was on a single industry, so that the population of the study was based 
on individuals operating a small to medium retail venture in Kinshasa. Low-income and medium-income enterprises are defined as enterprises that have less than 200 employees and whose turnover is less than FC11 200000 or $\$ 120000$ (Nest, Grignon \& Kisangani 2006). It was not possible to use random sampling due to practical considerations, such as the incomplete details of potential respondents and the absence of any comprehensive sampling frame. Consequently, by employing judgement sampling, 250 small venture ownermanagers were targeted; a final sample size of 126 was achieved and deemed to be appropriate for an empirical survey-based study. Moreover, owner-managers are typically well positioned in respect of the overarching performance of the entire venture (Matshekga \& Urban 2013).

Based on previous research, suitable measures were identified, particularly where there was theoretical and empirical support for each construct as examined in the literature review section. A survey was administered physically by trained field workers in Kinshasa who collected closed-ended questions from respondents. The questionnaires used a typical five-point Likert scale, which has been used extensively in similar studies (Seghers et al. 2009; Urban 2012). The questionnaire was purposively structured to determine levels of two dimensions of human capital, education and work experience, as well as to measure levels of venture performance.

Initially, the survey was in English, but as Kinshasa is a French-speaking city, was translated into French so that the respondents could understand and answer the questionnaire without any difficulty. In order to ensure that the instrument demonstrated sufficient face and content validity, a preliminary analysis via a pilot test on easily accessible retailers in Kinshasa was undertaken $(n=15)$. This procedure ensured that the respondents had no difficulties in answering the questions and that there was no problem in recording the data.

In line with previous research (Rauch et al. 2005; Urban 2012), demographic variables of owner-managers and characteristics of their ventures were captured. These variables included: age and gender of owner-manager, types of retailing involved in, the age and size of the venture, number of people supporting financially and the reason for starting the venture in the first place. These variables have been found to play a significant role in terms of venture performance (Ainin et al. 2010).

To measure the human capital dimension of education, several questions relating to the education of the ownermanager, both factual and perceptual questions (ratio and interval data respectively), were asked and included items such as: the perceived importance of their education, as well as of their employees in their success in the retail industry, the importance of education in general and frequency of attendance at seminars or short courses to enhance their education. The human capital dimension of work experience included questions also based on facts and perceptions and included items such as: quantity of experience working for others before starting own venture and relevance of previous work experience to current venture. The internal consistency and reliability of these scales based on perceptual items was tested by reporting on their Cronbach's alpha values; the aggregate scores for education and work experience were 0.76 and 0.81 respectively.

As per the hypotheses, the dependent variable for this study was venture performance and included both financial and non-financial indicators such as sales growth rate, operating profit, profit to sales ratio, market development and growth in product range and numbers of branches or stores (St-Pierre et al. 2010).

Data analysis involved both descriptive and inferential statistics based on the STATISTICA software system, version 10. Descriptive statistics were calculated and a correlation matrix was constructed to test the hypotheses. Cluster analysis was then employed, the main objective being to partition a set of ventures into two or more groups based on their performance indicator similarities. Using K-means clustering, where responses were clustered in terms of all the study variables, two clear clusters emerged (cluster 1: $n=43$ and cluster 2: $n=83$ ). Cluster analysis helps with relationship identification and was deemed suitable to test the hypotheses. Thus, instead of viewing observations as unique, these firms could be viewed as members of clusters and could be profiled by their general characteristics. Chi-square tests with Cramer's $\mathrm{V}$ effect size and $t$-tests with Cohen's effect size were reported to identify if the mean differences between clusters were weak, moderate or strong. Once clusters were defined and the underlying structure of the data represented in the clusters analysed then relationships amongst the observations that are typically not possible with the individual observations could be revealed (Hair et al. 2010).

\section{Results}

In order to test the hypotheses, descriptive statistics and a correlation matrix were constructed. The hypotheses were formulated to reflect the aggregate education-performance and work experience-performance relationships and are consequently presented as consolidated scores at this first level of analysis.

The Pearson correlation coefficients are reported with levels of significance denoted in Table 1. The interpretation of these correlations and the corresponding levels of significance allowed for acceptance or rejection of the hypotheses, as follows:

Education as a component of human capital was positively and significantly correlated with venture performance $(r=0.47$, $p<0.01$ ), providing support for hypothesis 1 .

Work experience as a component of human capital was positively and significantly correlated with venture performance $(r=0.35$, $p<0.05)$, providing support for hypothesis 2 .

In line with the study design objective to unpack the results and partition the sample into two or more groups based on their performance indicator similarities, cluster sampling 
TABLE 1: Descriptives and correlations for variables.

\begin{tabular}{|c|c|c|c|c|c|c|c|c|}
\hline Number & Variable & Mean & SD & 1 & 2 & 3 & 4 & 5 \\
\hline 1 & Education & 3.186 & 0.751 & 1 & - & - & - & - \\
\hline 2 & Work experience. & 2.981 & 0.670 & $0.485 * *$ & 1 & - & - & - \\
\hline 3 & Venture performance. & 3.085 & 0.697 & $0.470 * *$ & $0.350 *$ & 1 & - & - \\
\hline 4 & Age of venture. & 1.991 & 0.842 & 0.142 & 0.032 & 0.161 & 1 & - \\
\hline 5 & Employees in venture. & 1.534 & 0.844 & 0.072 & 0.177 & 0.168 & 0.195 & - \\
\hline
\end{tabular}

$*, p<0.05 ; * *, p<0.01$, two-tailed

TABLE 2: Sample characteristics per cluster.

\begin{tabular}{|c|c|c|c|c|c|}
\hline Variable & Categories & Cluster count 1 & Cluster count 2 & Cluster $1(\%)$ & Cluster $2(\%)$ \\
\hline \multirow[t]{3}{*}{ Types of retailing. } & Service retailing & 12 & 72 & 28 & 87 \\
\hline & Food retailing & 24 & 2 & 56 & 2 \\
\hline & Merchandise retailing & 7 & 9 & 16 & 11 \\
\hline \multirow[t]{4}{*}{ Duration of ownership in years. } & $1-2$ & 1 & 2 & 2 & 2 \\
\hline & $3-5$ & 10 & 35 & 23 & 42 \\
\hline & $6-9$ & 20 & 17 & 47 & 20 \\
\hline & $10+$ & 12 & 29 & 28 & 35 \\
\hline \multirow[t]{2}{*}{ Gender. } & Male & 33 & 58 & 77 & 70 \\
\hline & Female & 10 & 25 & 23 & 30 \\
\hline \multirow[t]{4}{*}{ Age you started venture. } & $15-21$ & 1 & 8 & 2 & 10 \\
\hline & $22-30$ & 8 & 28 & 16 & 34 \\
\hline & $31-39$ & 18 & 21 & 42 & 24 \\
\hline & $40+$ & 16 & 26 & 37 & 31 \\
\hline \multirow[t]{7}{*}{ Reasons for starting venture. } & Self-accomplishment & 19 & 18 & 44 & 22 \\
\hline & Want to be my own boss & 1 & 14 & 2 & 17 \\
\hline & More influence & 0 & 3 & 0 & 4 \\
\hline & More security & 16 & 2 & 37 & 2 \\
\hline & Family business tradition & 2 & 2 & 5 & 1 \\
\hline & Financial necessity & 5 & 24 & 12 & 29 \\
\hline & No decent jobs in the country & 0 & 20 & 0 & 24 \\
\hline \multirow{4}{*}{$\begin{array}{l}\text { People you support financially } \\
\text { through venture earnings. }\end{array}$} & 0 & 4 & 50 & 9 & 60 \\
\hline & $1-2$ & 36 & 23 & 84 & 28 \\
\hline & $3-5$ & 3 & 8 & 7 & 10 \\
\hline & $6-10$ & 0 & 2 & 0 & 2 \\
\hline \multirow[t]{3}{*}{ Employee numbers now in venture. } & $1-2$ & 24 & 48 & 56 & 58 \\
\hline & $3-5$ & 14 & 28 & 33 & 34 \\
\hline & $6-10$ & 5 & 7 & 12 & 8 \\
\hline
\end{tabular}

results are presented in Table 2. Select observations are that three different categories are represented in terms of retailing types, with cluster 2 dominating in service retailing (87\%), whilst cluster 1 dominates in food retailing (56\%). In terms of duration of venture ownership, cluster 2 shows the majority $(42 \%)$ of ownership in the three to five years category, whilst cluster 1 has a majority (47\%) ownership in the six to nine years category. For the variable 'reasons for starting a venture', the majority (44\%) in cluster 1 nominated 'self-accomplishment', whilst in cluster 2 the majority (29\%) nominated 'out of financial necessity'.

In order to further analyse the data it was first necessary to analyse the frequency and percentage of responses in terms of types and levels of education and work experience. These results are presented in Table 3 . The following is observed: the majority $(60 \%)$ of respondents in cluster 1 as well as in cluster $2(63 \%)$ had completed high school level. The majority $(53 \%)$ of respondents in cluster 1 required a bachelor's degree of their employees, whilst for cluster 2 the majority $(35 \%)$ required a postgraduate degree. For the variable 'work experience before starting your venture', the majority $(72 \%)$ in cluster 1 indicated two to three years prior work experience, whilst for cluster 2 the majority (54\%) indicated one year prior work experience.

Table 4 shows the frequency and percentage cluster results in terms of the different performance indicators; it is observed that for employee growth, the majority in cluster 1 (53\%) and in cluster 2 (59\%) added one new employee in the last three years. In terms of turnover growth percentage over the last three years, the majority in both cluster 1 (98\%) and cluster $2(95 \%)$ were in the $10 \%-19 \%$ growth category. In terms of branches or outlets added over the last three years, for both clusters the majority of respondents indicated zero additions.

Chi-square tests with Cramer's V effect size are reported in Table 5, in order to identify if the mean differences between clusters were weak, moderate or strong. The cutoffs for weak, moderate and strong effect sizes were based on established benchmarks: weak $=0.10$, moderate $=0.30$ and strong $=0.50$ (Hair et al. 2010). Several significant values and effect sizes 
TABLE 3: Types and levels of education and work experience.

\begin{tabular}{|c|c|c|c|c|c|}
\hline Variables & Categories & Cluster 1 & Cluster 2 & Cluster $1(\%)$ & Cluster $2(\%)$ \\
\hline \multirow[t]{3}{*}{ Highest level of education completed. } & Primary school & 7 & 2 & 16 & 2 \\
\hline & High school & 26 & 52 & 60 & 63 \\
\hline & Bachelor's degree & 10 & 29 & 23 & 35 \\
\hline \multirow{3}{*}{$\begin{array}{l}\text { Number of seminars or short courses attended for venture } \\
\text { creation in last five years. }\end{array}$} & Never & 2 & 44 & 5 & 53 \\
\hline & $1-5$ & 27 & 31 & 63 & 37 \\
\hline & $6-11$ & 14 & 6 & 33 & 7 \\
\hline \multirow[t]{5}{*}{ Education you require of your employees. } & No specific requirement & 0 & 27 & 0 & 33 \\
\hline & Primary school & 1 & 2 & 2 & 2 \\
\hline & High school & 3 & 20 & 7 & 24 \\
\hline & Bachelor's degree & 23 & 5 & 53 & 6 \\
\hline & Postgraduate degree & 16 & 29 & 37 & 35 \\
\hline \multirow{2}{*}{$\begin{array}{l}\text { Number of times you have sent employees for further } \\
\text { training in last year. }\end{array}$} & 0 & 2 & 4 & 5 & 5 \\
\hline & $2+$ & 41 & 24 & 95 & 29 \\
\hline \multirow[t]{5}{*}{ Your work experience before starting own venture. } & 1 year & 1 & 45 & 2 & 54 \\
\hline & $2-3$ years & 31 & 24 & 72 & 29 \\
\hline & $4-5$ years & 8 & 10 & 19 & 12 \\
\hline & $6+$ years & 3 & 3 & 7 & 4 \\
\hline & Not applicable & 0 & 1 & 0 & 1 \\
\hline
\end{tabular}

TABLE 4: Performance indicators.

\begin{tabular}{|c|c|c|c|c|c|}
\hline Variable & Categories & Cluster 1 & Cluster 2 & Cluster $1(\%)$ & Cluster $2(\%)$ \\
\hline \multirow{5}{*}{$\begin{array}{l}\text { Employee growth - number of staff increased in } \\
\text { last three years. }\end{array}$} & $5+$ & 1 & 2 & 2 & 2 \\
\hline & 4 & 12 & 10 & 28 & 12 \\
\hline & 3 & 2 & 10 & 5 & 12 \\
\hline & 2 & 5 & 12 & 12 & 14 \\
\hline & 1 & 23 & 49 & 53 & 59 \\
\hline \multirow[t]{4}{*}{ Turnover growth percentage over the last three years. } & $80+$ & 0 & 1 & 0 & 1 \\
\hline & $20-49$ & 0 & 2 & 0 & 2 \\
\hline & $10-19$ & 42 & 79 & 98 & 95 \\
\hline & $0-10$ & 0 & 1 & 0 & 1 \\
\hline \multirow{4}{*}{$\begin{array}{l}\text { Expansion of product or services in percentage over the } \\
\text { last three years. }\end{array}$} & $60+$ & 0 & 16 & 0 & 19 \\
\hline & $31-59$ & 0 & 44 & 0 & 53 \\
\hline & $11-30$ & 42 & 5 & 98 & 6 \\
\hline & $0-10$ & 1 & 18 & 2 & 22 \\
\hline & 0 & 28 & 65 & 65 & 78 \\
\hline & $1-3$ & 11 & 17 & 26 & 20 \\
\hline & $4-5$ & 4 & 0 & 9 & 0 \\
\hline
\end{tabular}

TABLE 5: Differences in clusters on performance variables.

\begin{tabular}{lll}
\hline Variable & Chi- square value & $p$-value \\
\hline Employees now in venture. & $\chi 2(1)=0.05$ & 0.8282 \\
Employees when you started venture. & $\chi 2(2)=10.99$ & 0.0041 \\
Employee growth in last three years. & $\chi 2(9)=22.51$ & 0.0074 \\
Current monthly turnover of venture. & $\chi 2(1)=117.26$ & 0.0000 \\
Turnover growth in last three years. & $\chi 2(4)=121.61$ & 0.0000 \\
Percentage turnover growth in last three years. & $\chi 2(1)=94.22$ & 0.0000 \\
Monthly turnover when first started venture. & $\chi 2(1)=109.15$ & 0.0000 \\
Expecting turnover growth over the next two years. & $\chi 2(1)=71.42$ & 0.0000 \\
Expanded product or services in last three years. & $\chi 2(3)=101.91$ & 0.42 \\
Branches added in last three years. & $\chi 2(1)=2.97$ & 0.0000
\end{tabular}

are noted in Table 5, including: 'the number of employees the entrepreneurs had when they first started their ventures' $\chi^{2}=10.99(0.004)$ with an effect size of 0.30 . Similarly 'employee growth' was significant at $\chi 2=222.51(0.007)$ and an effect size of 0.42 . Moreover, the results indicate a statistical difference regarding 'current turnover of venture' 
TABLE 6: $T$-tests on main variables: Grouping calculated on cluster number: Group $1(n=43)$; Group $2(n=83)$.

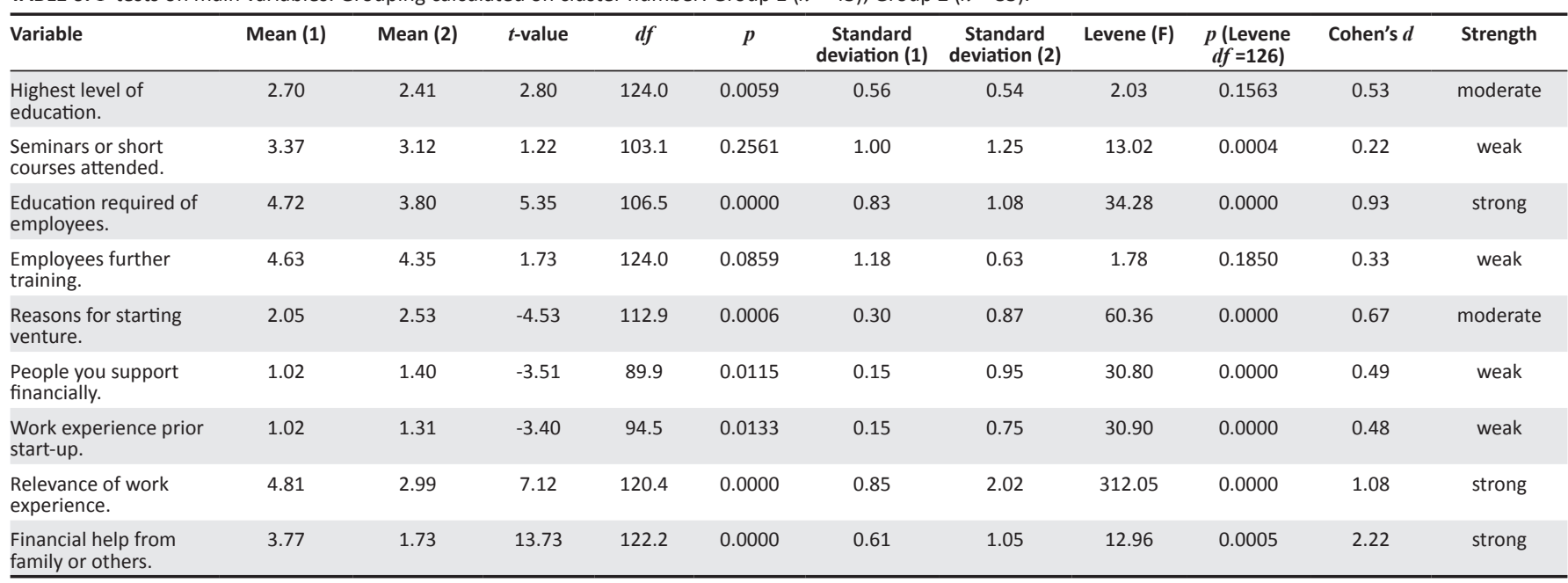

with a $\chi 2=117.26(0.000)$ and an effect size of 0.96 . Several other variables were also significant with varied effect sizes reported in the last column of Table 5.

T-tests were run on all the variables pertaining to human capital education and work experience, using Cohen's $d$ effect size to determine if the mean differences between these variables were weak, moderate or strong $(0.20 / 0.50 / 0.80)$ (Hair et al. 2010). Table 6 shows the results per cluster grouping. The results were interpreted as follows: for the variable 'highest level of education' the mean score (2.70) for cluster 1 versus the mean score (2.41) for cluster 2 rendered a significant $t$-value of 2.80 (0.005). Moreover, for this variable no significant difference between standard deviation for the clusters was observed, whilst a Cohen's $d$ effect size indicated that the mean differences may be considered moderate (0.53). Consequently, it can be deduced that there is relatively little difference amongst the clusters when it comes to the importance of 'highest level of education' in terms of performance. The same procedure was conducted for all the other variables and few other significant differences, albeit varied effect sizes, were detected.

It is interesting to note that for the work experience variables, the difference between clusters can be seen clearly in the last two variables in Table 6, where 'relevance of previous work experience' and 'financial help from family/others' both had mean values that are very different, so that their $t$-values are both very high and significant at $(p<0.000)$ with Cohen's $d$ effect values of 1.08 and 2.22 for cluster 1 and cluster 2 respectively, which is considered to be strong.

To further understand how the clusters differed in terms sample characteristics, additional chi-square tests were conducted on the categorical variables with Cramer's V effect size used to determine if the mean differences were weak, moderate or strong $(0.10 / 0.30 / 0.50)$. See Table 7 for full results. For the variable 'type of retailing', a chi-square and significant result was obtained ( $\chi 2=54.52 ; p=0.000)$, with a Cramer's V effect size of 0.66 indicating that the mean difference may be considered strong. The results for other variables were less convincing, such as: 'duration owned venture' ( $\chi 2=10.05 ; p=0.0182)$ had a Cramer's V effect size of 0.28 , which indicates that the mean difference is weak, whilst for gender $(\chi 2=1.06 ; p=0.3023)$, the Cramer's V effect size of 0.09 indicates that the mean difference was weak.

\section{Discussion and recommendations}

By building on existing theory and empirical studies this study set out to determine to what extent the human capital variables of education and experience play a role in venture performance. A diverse sample of entrepreneurs operating in the retail sector in the greater Kinshasa area was assembled to empirically determine levels of human capital variables and their importance to venture performance. Based on the results, several variables pertaining to education and prior work experience were related to different aspects of venture performance, allowing for support of the hypotheses. Nonetheless, when clustering was conducted some surprising results were observed; for instance, the venture performed well in terms of turnover, whilst owner-managers tended to havelittle experience (averaging less than two years) and perceived higher levels of education to be unrelated to increased performance. Such anomalies may partly be explained by external conditions that can lead to even well-educated people being presented with limited opportunities for satisfying and sufficiently rewarding employment, which leads to entrepreneurship attracting individuals with high levels of human capital. As a result, many entrepreneurs in transitional environments are well equipped to identify and exploit opportunities as they emerge over time, even if the initial reasons for becoming an entrepreneur may reasonably be described as 'necessity' (Urban 2012).

The empirical results emanating from this study resonate with past studies where the contribution of human capital to venture performance for SMEs in Ghana has been demonstrated (Saffu et al. 2008). Similar studies in South Africa have exposed the importance of human capital in ventures: entrepreneurs who possess a synergistic combination of education with industry managerial experience have the competencies and capabilities to manifest better results (Urban et al. 2008). The 
TABLE 7: Differences between clusters on sample characteristics.

\begin{tabular}{|c|c|c|c|c|}
\hline Variable & Categories & Chi-square value & $p$-value & Effect size \\
\hline \multirow[t]{3}{*}{ Types of retailing offered. } & Service retailing & $\chi 2(2)=54.52$ & 0.0000 & 0.66 \\
\hline & Food retailing & - & - & - \\
\hline & Merchandise retailing & - & - & - \\
\hline \multirow[t]{3}{*}{ Duration of ownership in years. } & $1-2$ & $\chi 2(3)=10.05$ & 0.0182 & 0.28 \\
\hline & $3-4$ & - & - & - \\
\hline & $5-9$ & - & - & - \\
\hline \multirow[t]{2}{*}{ Gender. } & Male & $\chi 2(1)=1.06$ & 0.3023 & 0.09 \\
\hline & Female & - & - & - \\
\hline \multirow[t]{4}{*}{ Age you started venture. } & 1521 & $\chi 2(2)=7.6$ & 0.0224 & 0.25 \\
\hline & $22-30$ & - & - & - \\
\hline & $31-39$ & - & - & - \\
\hline & $40+$ & - & - & - \\
\hline \multirow{6}{*}{ Reasons for starting venture. } & Want to be my own boss & - & - & - \\
\hline & More influence & - & - & - \\
\hline & More security & - & - & - \\
\hline & Family business tradition & - & - & - \\
\hline & Financial necessity & - & - & - \\
\hline & No decent jobs in the country & - & - & - \\
\hline \multirow[t]{4}{*}{ People you are supporting financially (including yourself). } & 0 & $\chi 2(2)=36.83$ & 0.0000 & 0.54 \\
\hline & $1-2$ & - & - & - \\
\hline & $3-5$ & - & - & - \\
\hline & $6-10$ & - & - & - \\
\hline
\end{tabular}

ability to accumulate new knowledge is positively related to the existing stock of knowledge including both knowledge formally acquired through education and knowledge tacitly acquired whilst accumulating experience in a particular domain (Unger et al. 2011). Several authors have argued that resources and assets (both tangible and intangible) are accumulated throughout entrepreneurial careers and are important in building a human capital base. Human capital represents an investment in education and skills and entrepreneurs provide tangible and intangible resources to a firm. Individuals accumulate these intangible resources through education and experience (Gimmon \& Levie 2009).

There are important practioner, policy and research implications related to the topic under investigation. Practioners need to be aware of how previous experience impacts firm performance. Firstly, it leads to the development of experientially acquired skills or expertise, which will lead in turn to more knowledgeable actions and decisions. Secondly, as founders are inclined to start businesses that are similar (e.g. in terms of industry or geographic area) to organisations with which they are familiar, experience influences the start-up characteristics (Unger et al. 2011).

The study results also offer guidance to practitioners in terms of how:

- Human capital is related to levels of education of founder and employees, which in turn positively impacts venture performance.

- Education is helpful for acquiring other utilitarian resources such as financial and physical capital and may partially compensate for a lack of financial capital.
- Human capital increases the capability of owners to perform the generic entrepreneurial tasks of discovering and exploiting business opportunities.

- Prior experience increases the owner-managers' entrepreneurial alertness, preparing them to discover specific opportunities that are not visible to other people.

- Prior business experience has been associated with assets like extended networks, increased expertise and a solid reputation with financiers, customers and suppliers.

In a broader African context the study has relevance as entrepreneurship is pivotal not only to transitional economies such as the DRC, but also to sub-Saharan Africa, where huge change is taking place and where the growth in the GDP per capita is one of the highest in the world, albeit from a very low base. High poverty and unacceptable levels of unemployment are prevalent in most African countries and some of these problems may be addressed through entrepreneurial activity. Whilst entrepreneurship may not be a panacea, it can most certainly form part of the solution (Herrington \& Kelly 2012). Against this backdrop, researching human capital dimensions and venture performance in Africa and emerging markets is valuable as recent research has found that the matching of entrepreneurial human capital with opportunities for growth and performance is the essence of economic development (Matshekga \& Urban 2013). Consequently, the focus on human capital as a driver of venture performance as entrepreneurs leverage their education and prior work experience to create and deliver value is an important predictor of growth in an African and emerging market context.

The study is not without limitations. For instance, there was an absence of analysis of firm survivor bias in the study sample. 
This is, in principle, an important methodological issue because firm survival itself may be determined by human capital (Unger et al. 2011). Consequently, the results of the study cannot be generalised to all business ventures. Future studies could build on the different configurations of human capital to assess how these clusters relate to firm survival rates. Researchers could also investigate how the human capital dimensions are complemented by social capital, particularly as social capital is one of the most significant sources of knowledge for entrepreneurs. Finally, future studies could focus on the fact that Kinshasa is a city with a multi-ethnic population and many foreigners living within its boundaries (Nsokimieno et al. 2010). Consequently, studies of a similar nature could consider the relationship between the various dimensions of human capital and performance from the perspective of the different ethnic groups as well as the country of origin of the entrepreneur, allowing for more fine-grained analysis.

\section{Acknowledgements Competing interests}

The authors declare that they have no financial or personal relationship(s) that may have inappropriately influenced them in writing this article.

\section{Authors' contributions}

B.U. (Wits Business School) wrote the article and helped conceptualise the study, whilst M.K. (Wits Business School) collected the data and interpreted the findings.

\section{References}

Ainin, S., Kamarulzaman, Y., Farinda, A.G. \& Azmi, A.C., 2010, 'Venture and entrepreneur characteristics influence on venture performance of professional small medium enterprises', paper presented at the Proceedings of the European Conference on Entrepreneurship \& Innovation, Venice, Italy, 03-05 June.

Amaral, M., Baptista, R. \& Lima, F., 2011, 'Serial entrepreneurship: Impact of human capital on time to re-entry', Small Venture Economy 37(1), 21.

Autio E., 2007, Report on high-growth entrepreneurship. Global entrepreneurship monitor report, Babson College and London Business School, Babson Park, MA and London, viewed n.d., from http://www.gemconsortium.org

Awogbenle, A.C. \& Iwuamadi, K.C., 2010, 'Youth unemployment: Entrepreneurship development programme as an intervention mechanism', African Journal of Business Management 4(6), 831-835.

Becker, G.S., 1964, Human capital: A theoretical and empirical analysis, with special reference to education, University of Chicago Press, Chicago, IL.

Borchert, P. \& Zellmer-Bruhn, M., 2010, 'Great expectations: The influence of human and relational capital on the magnitude of early venture goals', Journal of Applied Management and Entrepreneurship 15(4), 71.

Chawla, S.K., Khanna, D. \& Chen, J., 2010, 'Are small venture critical success factors same in different countries?', Journal of Management 7(1), 1-12.

Chisala, C., 2008, 'Unlocking the potential of Zambian micro, small and medium entreprises: Learning from the international best practices - the South East Aslan experience', IDE Discussion Paper No. 134, February, Institute of Developing Economies, Japan External Trade Organization (JETRO), Osaka, Japan.

Coyne, C.J. \& Pellillo, A., 2011, 'The art of seeing like a state: State building in Afghanistan, the DR Congo, and beyond', Review Austrian Economics 25(1), 52.

Davidsson, P., 2004, Researching entrepreneurship: International studies in entrepreneurship, Springer, New York, NY.

Davidsson, P. \& Honig, B.L., 2003, 'The role of social and human capital among nascent entrepreneurs', Journal of Business Venturing 18(3), 301-331. http://dx.doi. org/10.1016/S0883-9026(02)00097-6

Dobbs, M. \& Hamilton, R.T., 2007, 'Small business growth: Recent evidence and new directions', International Journal of Entrepreneurial Behaviour and Research 13(5), 296-322. http://dx.doi.org/10.1108/13552550710780885

Gimmon, E. \& Levie, J., 2009, 'Instrumental value theory and the human capital of entrepreneurs', Journal of Economic Issues 43(3), 732-748. http://dx.doi. org/10.2753/JEI0021-3624430307
Hair, J.F., Black, W.C., Babin, B.J. \& Anderson, R.E. (eds.), 2010, Multivariate data analysis: A global perspective, 7th edn., Pearson, Upper Saddle River, NJ.

Herrington, M. \& Kelly, D., 2012, African entrepreneurship: Sub-Saharan African regional report, International Development Research Centre, Canada, viewed n.d., from http://www.gemconsortium.org

Hitt, M.B., Shimizu, L.K. \& Kochhar, R., 2001, 'Direct and moderating effects of human capital on strategy and performance in professional service ventures: A resourcebased perspective', Academy of Management Journal 44(1), 13-21. http://dx.doi. org/10.2307/3069334

Iyenda, G., 2005, 'Street enterprises, urban livelihoods and poverty in Kinshasa', Environment and Urbanization 17(2), 55-67. http://dx.doi. org/10.1177/095624780501700205

Krueger, N.F. \& Brazael, D.V., 1994, 'Entrepreneurial potential and potential entrepreneurs', Entrepreneurship Theory and Practice 18, 91-105.

La Porta, R. \& Schleifer, A., 2008, 'The unofficial economy and economic development', working paper no. 14520, National Bureau of Economic Research, Massachusetts.

Mansor, M. \& Othman, N., 2011, 'CoBLAS: Inculcating entrepreneurial culture among higher education institutions' students', International Journal of Social Science and Humanity 1(1), 86-91. http://dx.doi.org/10.7763/IJSSH.2011.V1.15

Matshekga, M. \& Urban, B., 2013, 'The importance of the human capital attributes when accessing financial resources', Journal of Contemporary Management 10(15), 259-278.

McDade, B.E. \& Spring, A., 2005, 'The "New generation of African entrepreneurs": Networking to change the climate for business and private sector-led development', Entrepreneurship and Regional Development 17, 17-42. http:// dx.doi.org/10.1080/0898562042000310714

Mitra, J., Abubakar, Y.A. \& Sagagi, M., 2011, 'Knowledge creation and human capital for development: The role of graduate entrepreneurship', Education and Training 53(5), 479.

Nest, M., Grignon, F. \& Kisangani, E.F., 2006, The Democratic Republic of Congo: Economic Dimensions of war and peace, vol. 53, Lynne Rienner, Boulder, CO.

Nsokimieno, M., Shouyu, C. \& Qin, Z., 2010, 'Sustainable urbanization's challenge in Democratic Republic of Congo', Journal of Sustainable Development 3(2), 242-252.

Oluwatobi, S. \& Ogunrinola, I.O., 2011, 'Government expenditure on human capital development: Implications for economic growth in Nigeria', Journal of Sustainable Development 4(3), 77-89. http://dx.doi.org/10.5539/jsd.v4n3p72

Rauch, A., Frese, M. \& Utsch, A., 2005, 'Effects of human capital and long-term human resources development on employment growth of small-scale businesses: A causal analysis', Entrepreneurship Theory and Practice 29, 681-698.

Reijonen, H. \& Kompula, R., 2007, 'Perception of success and its effect on small venture performance', Journal of Small Venture and Enterprise Development 14(4), 689-701. http://dx.doi.org/10.1108/14626000710832776

Roca-Puig, V., Beltra'n-Martn, I. \& Cipres, M.S., 2012, 'Combined effect of human capital, temporary employment and organizational size on venture performance', Personnel Review 41(1), 22-32.

Saffu, K., Apori, S., Mensah, A. \& Ahumatah, B., 2008, 'The contribution of human capital and resource-based view to small- and medium-sized tourism venture performance in Ghana', International Journal of Emerging Markets 3(3), 268-284. http://dx.doi.org/10.1108/17468800810883684

Schultz, T.W., 1970, 'The reckoning of education as human capital', in W.L. Hansen (ed.), Education, income and human capital. NBER studies in income and wealth, p. 35, Columbia University Press, New York, NY

Seghers, A. Manigart, S. \& Vanacker, T., 2009, 'The impact of human and social capital on entrepreneurs' knowledge of finance alternatives', working papers of Faculty of Economics, Ghent University, Ghent.

Shree, S. \& Urban, B., 2012, 'Internationalisation of South African SMEs: The role of capital factors', Acta Commercii 12, 186-199.

Statistica version 10, 2011, computer software, Statsoft Inc., Johannesburg, viewed n.d., from http://www.statsoft.com

St-Pierre, J., Julien, P.A. \& Morin, M., 2010, 'L'effet de l'âge et de la taille sur la performance financière et économique des PME [The effect of age and size on the financial and economic performance of SMEs]', Journal of Small Venture and Entrepreneurship 23(2), 287-306. http://dx.doi.org/10.1080/08276331.2010.10593487

Unger, J.M., Rauch, A., Frese, M. \& Rosenbusch, N., 2011, 'Human capital and entrepreneurial success: A meta-analytical review', Journal of Business Venturing 26, 341-358. http://dx.doi.org/10.1016/j.jbusvent.2009.09.004

Urban, B., 2012, 'A metacognitive approach to explaining entrepreneurial intentions', Management Dynamics 21(2), 16-33.

Urban, B., Van Vuuren, J. \& Barreira, J., 2008, 'High-growth entrepreneurs: The relevance of business knowledge and work experience on venture success', Journal of Contemporary Management 5, 58-71.

Von Broembsen, M., Wood, E. \& Herrington, M., 2005, Global Entrepreneurship Monitor, South African Report, Graduate School of Business, University of Cape Town, Cape Town, viewed n.d., from http://www.gemconsortium.org

Williams, C.C., 2007, 'The nature of entrepreneurship in the informal sector: Evidence from England', Journal of Developmental Entrepreneurship 12(2), 339-254. http:// dx.doi.org/10.1142/S1084946707000654

Xavier, R., Kelley, D., Kew, J., Herrington, M., Vorderwülbecke, A. \& GERA, 2013, Global Entrepreneurship Monitor 2012 Global Report, Babson College, viewed n.d., from http://www.gemconsortium.org

Yaw, D.A., 2007, 'Promoting the informal sector as a course of gainful employment in developing countries: Insights from Ghana', International Journal of Human Resource Management 18(6), 1063-1084. http://dx.doi. Journal of Human Resource Ma
org/10.1080/09585190701321716 